DOI: 10.19085/journal.sijmd031101

\title{
Comparative Analysis of Retail Banking Promotional Measures- A study of customer perception towards promotional strategies adopted by Indian Commercial Banks
}

Rajesh Shankar Sharma, Ph.D Scholar, IKG Punjab Technical University, Kapurthala, India

Dr N S Bhalla Director, Global Institute of Management, Amritsar, India.

OScholedge International Journal of Management \& Development (ISSN 2394-3378), Vol.03, Issue 11 (2016) pg185-193. Published by: Scholedge R\&D Center [www.theSCHOLEDGE.org] [Email: editorial@thescholedge.org]

\begin{abstract}
In today's competitive financial world, each financial institution is trying hard to get the maximum share in terms of profit, sales and customers. A customer may be salaried or self employed. Irrespective of the profession, he/she requires banking services like a requirement of loan, services of foreign exchange, safe deposit of money etc. In order to meet and exceed customer's expectations, Indian banks offer customized banking products. Bank main objective is to get new customer and to retain the existing one. In order to attract new customers, banks are adopting various promotional measures like sales promotion, advertising, personal selling and publicity. Which promotional measure is the most striking one and is liked by customers, poses a big question mark? In order to study the most preferred promotional measure, a survey is being conducted to know the customer preference. 50 customers, each from Axis Bank and IndusInd Bank, are selected for study. The outcome was astonishing as the customers of Axis Bank gives preference to public relation and customers of IndusInd bank gives preference to effective advertising.
\end{abstract}

Keywords: Bank, Customers, Perception, Promotion

\section{Introduction}

Promotion- $4^{\text {th }}$ P of Marketing

Marketing is playing an important role in the development of business. It mainly deals with customers. According to Kotler, "Marketing is managing profitable customer relationship". The twofold goal of marketing is to attract new customers by promising superior value and grow current customers by delivering satisfaction (Kotler, 2011). Marketing involves four $P$ i.e. Product, Price, Place and Promotion. Banks, FMCG companies, IT companies, Job portals, Gadgets manufacturing companies 
etc are using various promotional tools to stimulate the customer needs. Insurance companies are using emotive advertising while banks are focusing on customer needs and are inventing new customized products. Nevertheless, each company main objective is to make profit, retaining as well as attracting new customer

\section{Banks}

Indian Banking industry, which is called the backbone of the country's economy, has played a key role in development of Indian economy. It has achieved enormous appreciation for its strength, particularly in the wake of the worldwide economic disasters, which pressed its worldwide counterparts to the edge of fall down. A bank is a financial institution and a financial intermediary that accepts deposits and channels those deposits into lending activities, either directly by extending loans or indirectly through capital markets. A bank serves as a link between customers who have capital deficits and customers having capital surpluses. Although Banks may be focusing on various innovative promotional tools but still they are facing a problem of marketing myopia i.e. the mistake of paying more attention to the specific products a company offers than to the benefits and experiences produced by these products. While implementing various promotional measures, Banks need to be careful in setting the right level of expectations. If they set high expectations and are unable to fulfill them, they will face a high customer attrition rate. On the other side, if they set low expectation, it will make a bleak picture of brand. It is appropriate for the banks to set the right expectation and market accordingly.

Axis Bank is the third largest private sector bank in India. The Bank has a large footprint of 2402 branches and 12,922 ATMs spread across the country. The bank offer services like retail banking, business banking, loans, FOREX etc. Currently this bank is heavily advertising through its tag line "BADHTI KA NAAM ZINDGI" and had inducted Deepika Padukone as its brand ambassador

IndusInd Bank is one of the reputed banking brands in India. This bank is having 1277 ATM spread all over the country and is functioning through 685 branches. This bank offers various products like saving and current accounts, deposits, loans, forex, insurance etc. The bank has been continuously investing in various advertising \& marketing programs to enhance the brand image. Recently it advertised through brand ambassador Mr. Farhan Akhtar "Video Branch Banking services". This Bank is keeping in mind the demographic, psychographic features of Indian customers and thus is launching innovative services like Choice Money ATMs, Check-on-Cheque, Cash-on-Mobile, Direct Connect, Quick Redeem Service and 365 Days Banking. All these unique services have been widely publicized and have 
been well appreciated by the customers. The bank launched yet another innovative service called 'My Account My Number' where the customers can get Bank Account Numbers of their choice.

Review of Literature

Sharma (2007)- A study by the author on celebrity product endorsement found that consumers are not easily persuaded by a celebrity to go for a product/service. He/she also needs a comprehensive information about the product/service. Along with it, customer focus is also on brand name, overall appeal, and music/ jingle. Advertisements being endorsed by celebrities are found to be less attractive and that the use of celebrities may not change the buying behavior of consumers significantly.

B. Zafer Erdogan(1999) studied the use of celebrities as part of marketing communications strategy. He pointed out that firms invest significant funds in strengthening brands. Companies choose endorser who is attractive, likeable and trustworthy. These qualities operate in a transferable way, and, will generate desirable campaign outcomes.

Sudhahar, J.C (2004) If banks can understand which attributes are used to evaluate a service they will be better able to manage and influence the customer's evaluations and perception of the offering

Batra et al. (1995), the effectiveness of advertising should be considered for its effect on sales in the short term.

\section{Research Methodology}

A comparative research is being undertaken for the study of promotional measures adopted by Axis Bank and IndusInd Bank. Research is based on descriptive analysis. Primary data is collected from the customers of Axis and IndusInd for conducting research in Amritsar region only. Data is collected through direct interview and filling of questionnaires. A Non-probability convenience sampling was used and a sample size of 50 respondents from each bank was collected for study. Because of its limited region and time, this study may not be a detailed, full-fledged and utilitarian in all aspects.

Objective

"To study promotional measures adopted by Axis Bank and IndusInd Bank"

\section{Analysis and Result}

Table-1

Ranking method has been used to find out the most preferred element of promotion mix. Analysis has been done on the basis of weighted scores and scoring has been done as per the following scale:- 
I Rank = 5 weights, II Rank = 4 weights, III Rank =3 weights, IV Rank = 2 weights, V Rank = I weight

Table 1: Contribution of Different Components of Promotion Mix (Axis Bank)

\begin{tabular}{|l|l|l|l|l|l|l|l|l|}
\hline Rank Factors & $\begin{array}{l}\text { Rank } \\
\text { I }\end{array}$ & $\begin{array}{l}\text { Rank } \\
\text { II }\end{array}$ & Rank III & Rank IV & Rank V & $\begin{array}{l}\text { Weighted } \\
\text { Score }\end{array}$ & $\%$ & Rank \\
\hline Advertising & 16 & 12 & 21 & 7 & 16 & 221 & 30 & 2 \\
\hline Public Relations & 14 & 15 & 23 & 14 & 13 & 240 & 33 & 1 \\
\hline Personal Selling & 16 & 14 & 3 & 25 & 14 & 209 & 27 & 3 \\
\hline Sales Promotion & 2 & 5 & 2 & 2 & 5 & 45 & 6 & 4 \\
\hline Publicity & 2 & 4 & 1 & 2 & 2 & 35 & 4 & 5 \\
\hline Total & 50 & 50 & 50 & 50 & 50 & 750 & 100 & \\
\hline
\end{tabular}

The existing customers of Axis Bank have chosen its services on the basis of effective public relation. The relationship managers in Axis Bank are working excellent in strengthening their ties with its customers and this is resulting in attracting new customers also.

Table 2: Contribution of Different Components of Promotion Mix (IndusInd Bank)

\begin{tabular}{|l|l|l|l|l|l|l|l|l|}
\hline Rank Factors & $\begin{array}{l}\text { Rank } \\
\text { I }\end{array}$ & $\begin{array}{l}\text { Rank } \\
\text { II }\end{array}$ & Rank III & Rank IV & Rank V & $\begin{array}{l}\text { Weighted } \\
\text { Score }\end{array}$ & $\%$ & Rank \\
\hline Advertising & 20 & 16 & 24 & 7 & 19 & 269 & 36 & 1 \\
\hline Public Relations & 12 & 15 & 17 & 21 & 11 & 224 & 30 & 2 \\
\hline Personal Selling & 12 & 14 & 6 & 15 & 12 & 176 & 23 & 3 \\
\hline Sales Promotion & 4 & 1 & 2 & 4 & 6 & 44 & 6 & 4 \\
\hline Publicity & 2 & 4 & 1 & 3 & 2 & 37 & 5 & 5 \\
\hline Total & 50 & 50 & 50 & 50 & 50 & 750 & 100 & \\
\hline
\end{tabular}

Effective advertising is the most important criteria in selecting the services of IndusInd Bank. Customers of this bank are highly impressed by the advertising and thus have selected the services of IndusInd Bank.

Further, when we asked the customers about the most striking advertising media, their response was as follows: 
Table 3: Most Striking Advertising Media for Axis Bank and IndusInd Bank

\begin{tabular}{|l|l|c|l|c|l|}
\hline S.NO & Advertising Media & Axis Bank Customers & $\%$ & IndusInd Customers & $\%$ \\
\hline 1 & TV & 20 & 40 & 22 & 44 \\
\hline 2 & Magazines & 10 & 20 & 8 & 16 \\
\hline 3 & Internet & 3 & 6 & 4 & 8 \\
\hline 4 & Radio & 5 & 10 & 6 & 12 \\
\hline 5 & Newspaper & 12 & 24 & 10 & 20 \\
\hline & Total & 50 & 100 & 50 & 100 \\
\hline
\end{tabular}

Both the banks are efficiently promoting their brands on television and the same are liked by their customers. Advertisement in Magazine is the second most liked media.

Table-4 The customers of Axis Bank and IndusInd Bank were asked to rate overall performance of advertisements. In the case of Axis Bank, out of 50, 22 considered these advertisements to be impressive, 20 considered them to be average and rest 8 considered it to be dissatisfactory. Similarly in the case of IndusInd, out of 50, 24 were of the opinion that these advertisements are impressive, 22 gave them average rating and rest 4 considered these advertisements to be dissatisfactory.

Table 4: Customer Opinion about Advertising

\begin{tabular}{|l|l|l|l|l|l|}
\hline S.No & Opinion & No of Axis Customers & $\%$ & No of IndusInd Customers & $\%$ \\
\hline 1 & Satisfied & 22 & 44 & 24 & 48 \\
\hline 2 & Average & 20 & 40 & 22 & 44 \\
\hline 3 & Dissatisfied & 8 & 16 & 4 & 8 \\
\hline \multicolumn{2}{|l|}{ Total } & 50 & 100 & 50 & 100 \\
\hline
\end{tabular}

Both Axis Bank and IndusInd Bank are promoting their brand through their respective brand ambassadors. Both are heavily advertising on digital and print media. The customers of Axis Bank in Amritsar are appreciating the services of relationship managers and are referring Axis Bank more potential customers while the customers of IndusInd Bank are getting more attracted towards advertisements. Nevertheless, both the banks are trying hard to increase their market share in terms of customers and profits. 


\section{Factor Analysis}

Table 5: KMO and Bartlett's test for factors related to level of satisfaction towards the promotional measures

\begin{tabular}{|l|l|l|}
\hline \multicolumn{2}{|l|}{ KMO and Bartlett's Test } & .559 \\
\hline \multicolumn{2}{|l|}{ Kaiser-Meyer-Olkin Measure of Sampling Adequacy } & \\
\hline Bartlett's Test of Sphericity & Approx. Chi-Square & 9234.442 \\
\cline { 2 - 3 } & DF & 66 \\
\cline { 2 - 3 } & Sig. & $.000^{* *}$ \\
\hline
\end{tabular}

${ }^{* *} \mathrm{p}<0.01 \quad$ S- Significant

From the above table, two tests, namely Kaiser-Meyer-Olkin Measure of Sampling Adequacy (KMO) and Bartlett's Test of Sphericity have been applied to test whether the association among the variables has been significant or not. The Kaiser-Meyer-Olkin Measure of sampling adequacy shows that the value of test statistics is 0.559 , which means the factor analysis for the selected variable is found to be appropriate to the data. Bartlett's test of sphericity is used to test whether the data are statistically significant or not with the value of test statistics and the associated significance level. It shows that there exists a high association among variables.

Table-6 Eigen Values and Proportion of Total Variance of Each Underlying Factors Related to Level of Satisfaction towards the promotional measures adopted by banks

\begin{tabular}{|c|c|c|c|c|c|c|c|c|c|}
\hline \multicolumn{10}{|c|}{ Total Variance Explained } \\
\hline \multirow[t]{2}{*}{ Component } & \multicolumn{3}{|c|}{ Initial Eigen values } & \multicolumn{3}{|c|}{$\begin{array}{l}\text { Extraction sums of Squared } \\
\text { loading }\end{array}$} & \multicolumn{3}{|c|}{$\begin{array}{l}\text { Rotation sums of squared } \\
\text { loading }\end{array}$} \\
\hline & Total & $\begin{array}{l}\% \text { of } \\
\text { variance }\end{array}$ & $\begin{array}{l}\text { Cumulative } \\
\%\end{array}$ & Total & $\begin{array}{l}\% \text { of } \\
\text { variance }\end{array}$ & $\begin{array}{l}\text { Cumulative } \\
\%\end{array}$ & Total & $\begin{array}{l}\% \text { of } \\
\text { variance }\end{array}$ & $\begin{array}{l}\text { Cumulative } \\
\%\end{array}$ \\
\hline
\end{tabular}




\begin{tabular}{|l|l|l|l|l|l|l|l|l|l|}
\hline 1 & 7.079 & 58.990 & 58.990 & 7.079 & 58.990 & 58.990 & 5.471 & 45.588 & 45.588 \\
\hline 2 & 1.661 & 13.840 & 72.830 & 1.661 & 13.8402 & 72.830 & 2.940 & 24.498 & 70.086 \\
\hline 3 & 1.296 & 10.800 & 83.630 & 1.296 & 10.800 & 83.630 & 1.625 & 13.543 & 83.630 \\
\hline
\end{tabular}

Extraction Method: Principal Component Analysis

The results of the factor analysis presented in the above table represent the factors related to level of satisfaction towards promotional measures adopted by both the banks. The table reveals that there are twelve variables that had Eigen value exceeding "one". When the twelve variables are compressed into three factors, the first factor accounted for 58.990 percent of the variance, the second 13.84 percent, and last the factor 10.80 percent of the variance in the data set. The first three factors are the final factors solution and they all together represent 83.63 percent of the total variance in the scale items measuring the factors related to level of satisfaction.

Table-7 Factors related to level of satisfaction

\begin{tabular}{|c|c|c|c|}
\hline Code & Variable & Code & Factors \\
\hline $\mathrm{X} 1$ & Television & 82.45 & Factor-1 \\
\hline $\mathrm{X}_{2}$ & Direct Mail & 76.21 & \\
\hline $\mathrm{X} 11$ & Brochures & 70.90 & \\
\hline$x_{3}$ & In bank Display & 68.89 & \\
\hline $\mathrm{x} 8$ & Face to Face interaction & 56.25 & Factor-2 \\
\hline $\mathrm{X} 4$ & Sales Representative & 45.16 & \\
\hline$x_{5}$ & Tele marketing & 42.51 & \\
\hline $\mathrm{x}_{7}$ & Bank Coupons & 82.23 & Factor-3 \\
\hline $\mathrm{x} 6$ & Trade Shows & 74.34 & \\
\hline
\end{tabular}




\begin{tabular}{|c|c|c|}
\hline X9 & Exhibitions & 62.22 \\
\hline X11 & Newspaper & 55.43 \\
\hline $\mathrm{X} 10$ & Radio & 49.2 \\
\hline
\end{tabular}

\section{Conclusion}

Banks in India are taking up various promotional strategies to attract new customers and are offering a basket full of banking products to existing customers. Customers are now having an ample option in selecting the services of private, public or foreign bank. Banks needs to be vigilant in promoting their product and setting a right level of expectation and meeting them when effective service encounter takes place. Banks can choose a variety of promotional measure to endorse their product. Selecting an efficient promotional measure is a daunting task now days. But this daunting task is easily handled by Axis Bank and IndusInd Bank as both are performing exceptionally well in promoting their brands. Customers of Axis bank like the public relation aspect while customers of IndusInd like advertisement aspect. Customers of both banks have shortlisted Television as a striking advertising media. Both bank's customers are satisfied with the advertisement content.

\section{Bibliography}

1. B.Zafer Erdogan(1999), Celebrity Endorsement: A Literature Review, Journal of Marketing Management, pages 291-314, Volume 15, Issue 4.

2. Batra R., Lehman D.R., Burke J., Pae J. (1995), «When does advertising have an impact, A Study of Tracking Data», Journal of Advertising Research.

3. http://www.axisbank.com/download/CD-Shopaholics-Online-Festival-2nd-4th-September2014.pdf

4. http://www.axisbank.com/media-center/bank-profile.aspx

5. http://www.indiainbusiness.nic.in/studies_survey/Banking_systemsurvey.pdf

6. http://www.indusind.com/content/home/about-us/media-room/brand.html

7. Ms. Linda Mary Simon (2012), "A Study on Customer Perception Towards Services Provided by Public Sector Bank and Private Sector Bank", Indian Journal Of Research, Volume : 1, Issue : 12, December 2012, ISSN - 2250-1991

8. Philip Kotler, Gary Armstrong, Principles of Marketing ( Page 4, $13^{\text {th }}$ edition, Pearson Education, 2011.) 
9. S.M.Jha, Services marketing, Himalaya Publishers, 2010

10. Sharma Sandhir (2007), "Celebrities don't affect consumer decision making, says study", from www.indianmba.com/Faculty Column

11. Sudhahar, J.C., and Selvam, M.,“The Measurement of service Quality Perception in Banking Sector", SCMS Journal of Indian Management, Oct-Dec. 2004, pp. 37-51.

12. Ziethmal Valarie, Service Marketing: Integrating Customer focus across the firm ( fifth edition, New Delhi, The McGraw Hill, 2011. 